\title{
Export Restraints in a Dominant Firm Oligopoly**
}

\author{
David Yeung*
}

\begin{abstract}
This note examines the effects of foreign output restraints in a homogeneous product oligopoly with a dominant domestic firm. Both the domestic firm and the foreign firm gain from a restraint on foreign output if the foreign firm's reaction function is negatively sloped. The foreign firm would consider offerring an output restraint voluntarily. However, in the case when the foreign firm's reaction function is upward sloping, a foreign output restraint increases the market output, lower the market price, increases the domestic firm's profit and lower the foreign firm's profit. The imposition of a quota would raise output sold in the domestic market.
\end{abstract}

\section{Introduction}

The issue of export restraints has attracted increasing attention in the study of international economics. Coercive (involuntary) restraints on the exporting country are mainly in the form of quotas and tariffs. Bhagwati (1965 and 1968), McCullock (1973), Rodriguez (1974), Itoh and Ono (1982) and Krishna (1983) are studies on quotas and tariffs. Recently, the notion of voluntary export restraints (VER) arises. Takacs (1978), Lizondo(1984), Brecher and Bhagwati (1987), and Dinopoulos and Kreinin (1989) compare VER with alternative trade restrictions either in a partial equilibrium framework or in a general equilibrium framework. Feenstra (1984) demonstrates that VER has induced a shift toward

* Department of Economics, University of Hong Kong and University of Windsor.

** The author would like to thank an anonymous referee for his valuable suggestions. 
higher quality exports. Dinopoulos and Kreinin (1988) examine the effects of Japanese auto VER on European prices and on U.S. welfare. The foundation for VER is the incentives for foreign countries to bring about such an action. According to conventional arguments, foreign countries are benefited because an export duty collected by foreign governments replaces an import tariff collected by domestic authority under VER (see Brecher and Bhagwati (1987)). Another rationale is that VER may bring about a curtailment in lobbying competition among domestic and foreign suppliers. Harris (1985) and Krishna (1989) use a pricing game in a differentiated products duopoly to show that VER may raise industry prices and hence increases the profits of both the domestic firm and the foreign firm. The presence of VER impedes the ability of the foreign firm to compete in the domestic market, thereby facilitates collusion. Mai and Hong (1988) use a conjectural variations model to examine the condition under which VER are mutually beneficial in the Harris-Krishna framework. It is shown in their paper that if the free trade equilibrium is more (less) collusive than the Cournot zero conjectural variation situation, the imposition of VERs at the free trade level of foreign output leads to a decrease (an increase) in the profit of the foriegn firm. However, Makowsky (1987) shows that there is a serious flaw in conjectural variations models. In particular, they lack an optimization foundation. This posts a strong challenge to the use of such models in analysing economic behaviour.

In this paper, we deviate from Harris and Krishna's setting of a pricing game in a differentiated products market and consider an output game in a homogeneous product market. Neither rent-seeking lobbying nor export duty is present in the model. Furthermore, the domestic firm is assumed to be dominant in the sense that it acts as the leader in the market while the foreign firm acts as the follower. This scenario can be considered as the case in which the domestic firm can sell its product in the domestic market before the foreign firm can do so. Thus, we have a Stackelberg output game in which the domestic firm selects its output level taking into account the subsequent output responses of foreign competitors. The use of Stackelberg model in international trade analysis is not new. Itoh and Ono (1982) examine the effects of tariffs and quotas under different market structures. Fung (1989) examines the equivalence of tariffs and quotas in a Stackelberg models and shows that a dominant domestic firm prefers quotas to tariffs. In our analysis, we examine the incentives for foreign output 
restraints in such model. It is shown that the results depend on the response function of the foreign firm. If the foreign firm's response function is negatively sloped, both the domestic firm and the foreign firm would benefit from the VER. The domestic firm's (foreign firm's) profits can be higher even though the VER foreign output is greater (less) than the unrestrained foreign output. In this case, the foreign firm has an incentive to offer a voluntary restraint on its output. If the foreign firm's response is upward sloping, a foreign output restraint increases market output, lowers market price and raises the domestic firm's profit. This provides an argument for the imposition of a quota on foreign output by a domestic government who prefers higher supply of less expensive goods to consumers and higher profit for domestic firms.

\section{The Model}

Consider a trade model with a dominant domestic firm and a foreign firm. The market demand is

$$
P=f\left(q_{1}+q_{2}\right)
$$

where $q_{1}$ is the domestic firm's output, $q_{2}$ is the foreign supply and $P$ is the market price. Market demand is downward sloping and hence $f^{\prime}()<$.0 .

The cost of production of the domestic firm and that of the foreign firm are respectively

$$
c_{l}\left(q_{1}\right) \text { and } c_{2}\left(q_{2}\right)
$$

with $c_{i}^{\prime}()>0,. \quad c_{i}^{\prime \prime}(.) \geq 0 \quad i=1,2$

Given the domestic firm's output $q_{1}$, the foreign firm's reaction function $q_{2}=$ $\phi\left(q_{l}\right)$ is obtained by solving the following first order condition ${ }^{1}$ :

$$
f(.)+f^{\prime}(.) q_{2}-c_{2}^{\prime}(.)=0
$$

1 The second order condition $2 f^{\prime}+f^{\prime \prime} q_{2}-c_{2}^{\prime \prime}<0$ is assumed. 
Using the implicit function rule, the slope of the reaction function $\phi^{\prime}($.$) in$ (3) can be obtained as

$$
\frac{d \phi\left(q_{1}\right)}{d q_{1}}=-\frac{f^{\prime}+f^{\prime \prime} q_{2}}{2 f^{\prime}+f^{\prime \prime} q_{2}-c_{2}^{\prime \prime}} \gtrless 0 \quad \text { if } f^{\prime}+f^{\prime \prime} q_{2} \gtrless 0
$$

Note that the sign of $d \phi / d q$, is determined by the demand structure $f($.$) and has$ nothing to do with the degree of competitiveness among firms. ${ }^{2}$

Taking into account the foreign competitor's response, the domestic firm maximizes:

$$
\pi_{1}=f\left[q_{l}+\phi\left(q_{l}\right)\right] q_{l}-c_{l}\left(q_{l}\right)
$$

First order condition for a maximum is

$$
f(.)+\left(1+\phi^{\prime}(.)\right) q_{2} f^{\prime}(.)-c_{1}^{\prime}(.)=0
$$

Solving (5) yields a profit maximizing level of domestic output, $q_{I}{ }^{*}$. Upon substituting $q_{1}^{*}$ into $\phi($.$) , one can obtain the level of foreign supply q_{2}{ }^{*}=\phi\left(q_{1}^{*}\right)$. The output pair $\left(q_{1}^{*}, q_{2}^{*}\right)$ is the unrestrained Stackelberg (free-trade) equilibrium outcome.

Now, consider the case when there is a constraint such that foreign output cannot exceed $\hat{q}_{2}$. The domestic firm maximizes profits:

$$
\pi_{1}=f\left(q_{1}+q_{2}\right) q_{t}-c_{l}\left(q_{1}\right)
$$

2 Mai and Hong (1988) assume the existence of a constant conjectural variations $\lambda$, which measures $d q_{2} / d q_{1}$ and they claim that if $\lambda<(>) 0$, the firms are more (less) competitve than the Cournot case. Moreover Formby, Layson, and Smith (1982) has shown that the possibility of positively sloping marginal revenue exists anytime a convex demand function is under consideration. In particular the marginal revenue of the demand curve $P=f(Q)$ would be upward sloping if $f^{\prime}+f^{\prime \prime} \frac{Q}{2}>0$ where $Q$ is the market output. For instance, if the Stackelberg equilibrium at a point where the marginal revenue is rising and foreign output is no less than half of the total market share, its reaction function is positively sloped. 
subject to two constraints

$$
\begin{aligned}
& \phi\left(q_{1}\right) \geq q_{2} \\
& \hat{q_{2}} \geq q_{2}
\end{aligned}
$$

Constraint (7.1) states that the foreign firm would not produce more than its profit maximizing level of output (reflected by its optimal response function $\left.\phi\left(q_{1}\right)\right)$. Constraint (7.2) states that foreign output cannot be higher than the restraint level.

Let $\lambda$ and $r$ be the Lagrange multipliers associated with constraints (7.1) and (7.2) respectively, the domestic firm's profit maximization conditions include:

$$
\begin{aligned}
& f(.)+q_{1} f^{\prime}(.)-c_{1}^{\prime}(.)+\lambda \phi^{\prime}(.)=0 \\
& \phi\left(q_{1}\right)-q_{2} \geq 0 ; \lambda\left[\phi\left(q_{1}\right)-q_{2}\right]=0 \\
& \hat{q}_{2}-q_{2}>0 ; r\left[\hat{q}_{2}-q_{2}\right]=0
\end{aligned}
$$

In the case when $\phi\left(q_{1}\right)=q_{2}<\hat{q}_{2}$; constraint (7.1) is binding and $\lambda=q_{1} f^{\prime}($.$) .$ Condition (8.1) is the same as the Stackelberg outcome in (5). In the case when $\phi\left(q_{1}\right)>q_{2}=\hat{q}_{2}$, the foreign firm is restrained to produce $\hat{q}_{2}$ amount of output and $\lambda$ equals zero. Condition (8.1) requires the choice of $q_{1}$ to be consistent with $q_{2}=\hat{q}_{2}$ and

$$
f(.)+q_{1} f^{\prime}(.)-c_{1}^{\prime}(.)=0
$$

The domestic firm would let the foreign output to reach the restraining level $\hat{q}_{2}$ as long as the domestic firm's profits under restraint is higher than that in the unrestrained case.

Proposition 1: The domestic firm's profit with a foreign output restraint $\hat{q}_{2}=q_{2}{ }^{*}$ is higher than the domestic firm's free trade profit.

Proof: See Appendix A.

Q.E.D.

Moreover, one can establish;

Proposition 2: The domestic firm's profit is negatively related to the level of restrained foreign output $\hat{q}_{2}$ for $q_{2} \epsilon\left[0, q_{2}{ }^{0}\right]$ where $q_{2}{ }^{0}$ is the level of foreign 
output restraint at which the domestic firm's profit is the same as that in the unrestrained case.

Proof: See Appendix B.

Q.E.D.

Proposition 1 and 2 together shows that the domestic firm prefers having foreign output restraints to having no restraints. Moreover, the domestic firm's profit would increase even with a restraint of foreign output which is higher than the unrestrained level. In particular, the domestic firm's profit would increase with the imposition of a foreign output restraint $\hat{q}_{2}=\hat{q}_{2}{ }^{*}$ irrespective to whether $\phi^{\prime}($.$) is positive or negative. The intuition is as follows. If \phi^{\prime}()<$.0 , the domestic firm would use output as an instrument to discourage foreign supplies. With a foreign output restraint, the domestic firm does not have to produce excessively to curtail foreign competition. On the other hand, if $\phi^{\prime}()>$.0 , the domestic firm would reduce its output in order to induce the foreign firm to produce less. With a foreign output restraint, the domestic firm can increase its output with foreign output being bound by the restraint. Now, we turn to the foreign firm.

Proposition 3: The foreign firm's profit under a foreign output restraint $\hat{q}_{2}=\hat{q}_{2}{ }^{*}$ would be higher (lower) than the unrestrained foreign firm's profit if $\phi^{\prime}\left(q_{l}\right)$ is negative (positive).

Proof: See Appendix C.

Q.E.D.

For $\phi^{\prime}($.$) being negative, Proposition 3$ shows that the foreign firm's profit with a restraint of output at $q_{2}{ }^{*}$ is higher than its profits in the unrestrained case. Hence, an exports restraint is beneficial to the foreign firm and is voluntary. While the domestic firm would enjoy an increase in profit with an imposition of foreign output restraint, it would object to the voluntary action of the foreign firm.

Proposition 4: If $\phi^{\prime}($.$) is negative, there exists an interval of restrained level of$ foreign output $\left(q_{2}, q_{2}\right)$ such that the foreign firm's profit under restraint are higher than that in the unrestrained case. In particular $q_{2}<q_{2}{ }^{*}<\overline{q_{2}}$.

Proof: See Appendix D.

Proposition 5: If $\phi^{\prime}($.$) is positive, a foreign output restraint \hat{q}_{2}=q_{2}{ }^{*}$ would

(i) increase the market output,

(ii) decrease the market price,

(iii) increase the domestic firm's profit, and

(iv) decrease the foreign firm's profit. 
Parts (i)-(iv) of Proposition 5 are shown in the proofs of Propositions 1 and 3. Therefore, see Appendices A and C. Q.E.D.

Propositions 1-5 give interesting implications of export restraints in a dominant firm oligopoly. If the foreign firm's reaction function is negative, the foreign firm would voluntarily offer an restraint on its exports to the domestic country. The size of the VER can be greater than or less than the free trade level, $\mathrm{q}_{2}{ }^{*}$. If the foreign firm's reaction function is positive (at least around the equilibrium point), an interesting situation may arise. The domestic firm may request the domestic government to impose a quota on foreign output and promises to increase domestic output. The imposition of a quota leads to an increase in market output and a decrease market price. This creates a scenario in which the domestic government inclines to support a foreign output restraint.

For the aid of intuition, a diagrammatic analysis exhibiting the main results of the above analysis is given in Appendix E. ${ }^{3}$

\section{Concluding Remarks}

In a dominant domestic firm oligopoly, both the domestic firm and the foreign firm gain from a restraint on foreign output if the foreign firm's reaction function is negative. Therefore the restraint on foreign output will be voluntary from the foreign firm's point of view. This mutual gain exists even for restraints larger or smaller than the unrestrained level of foreign output. If the foreign firm's reaction function is positive, a foreign output restraint raises the dominant firm's profits, lowers the market price and increases the market output. The imposition of a quota on foreign output is socially preferred from the domestic country's point of view.

3 The author is very much indebted to the anonymous referee for the drawing of these diagram. 


\section{Appendices}

\section{Appendix A \\ Proof of Proposition 1}

Since foreign output cannot exceed $q_{2}{ }^{*}$, the domesitc firm can choose $q_{1}^{*}$ and obtain the same profit as that in the unrestrained case if it wishes to do so. Note that the domestic firm would not push foreign output to a level lower than $q_{2}{ }^{*}$ because that would give the domestic firm a lower level of profit than that in the unrestrained case. Therefore the constraint $\hat{q}_{2}=q_{2}{ }^{*}$ is binding while constraint (7. 1 ) is not. Hence, condition ( $\left.8.1^{\prime}\right)$ is in effect. A comparison of the first order conditions shows that $q_{1}$ under a foreign output restraint $\hat{q}_{2}=q_{2}{ }^{*}$ in $\left(8.1^{\prime}\right)$ is, in general, not identical to $q_{1}^{*}$ in (5). Given that a domestic output other than $q_{1}^{*}$ is chosen in the restrained case, the domestic firm's profit with a foreign output restraint at $q_{2}{ }^{*}$ must be higher than that in the unrestrained case.

\section{Appendix B}

\section{Proof of Proposition 2}

For a given level of restrained foreign output $\hat{q}_{2}$ the domestic firm's profit is the same as that in the unstrained case, that is

$$
\pi_{1}^{*}=f\left(q_{1}^{*}+q_{2}^{*}\right)-c_{I}\left(q_{1}^{*}\right)
$$

if constraint (7.1) is binding and foreign output is less than $\hat{q}_{2}$.

If constraint (7.2) is binding, the domestic firm's profit is

$$
\pi_{1}^{c}=f\left(q_{I}^{c}+\hat{q}_{2}\right) q_{I}^{c}-c_{I}\left(q_{I}^{c}\right)
$$

where $q_{I}^{c}$ is the choice which satisfies $f\left(q_{1}^{c}+\hat{q}_{2}\right)+q_{I}^{c} f^{\prime}\left(q_{I}^{c}+\hat{q}_{2}\right)-c_{1}^{\prime}\left(q_{l}^{c}\right)=0$. Differentiating $\pi_{1}^{\mathrm{c}}$ with respect to $\hat{q}_{2}$ yields 


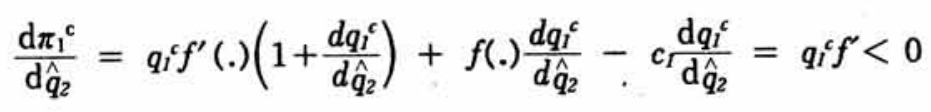

Note that $\pi_{1}{ }^{\mathrm{c}}$ increases as $\hat{\mathrm{q}}_{2}$ decreases. Let $q_{2}^{o}$ be the level of $\hat{\mathrm{q}}_{2}$ such that the domestic firm's profit is $\pi_{1}^{*}$. Therefore $\pi_{1}^{c}$ is at least as large as $\pi_{1}^{*}$ for $\hat{q}_{2} \epsilon\left(0, q^{g}\right)$ with constraint (7.2) being binding.

Q.E.D.

\section{Appendix C}

\section{Proof of Proposition 3}

The domestic firm's output in the unrestrained case satisfies (5) and in the restrained case, $q_{t}$ satisfies $\left(8.1^{\prime}\right)$ if $\hat{q}_{2}=q_{2}{ }^{*}$ is binding. Given that $f^{\prime}()<$.0 and $c_{1}^{\prime \prime}()>$.0 , domestic output under a restraint is less (greater) than that in the unrestrained case if $\phi^{\prime}\left(q_{l}\right)$ is negative (positive). Note that if $\phi^{\prime}()<.0(>0)$ a decrease (an increase) in domestic output induces the foreign firm to increase output. Hence, the restrained level $\hat{q}_{2}=q_{2}{ }^{*}$ is produced by the foreign firm. Therefore market price increases (decreases) and the foreign firm receives a higher (lower) united price for each of the $q_{2}{ }^{*}$ amount of output produced if $\phi^{\prime}$ (.) is negative (positive). Hence Proposition 3.

\section{Appendix D \\ Proof of Proposition 4}

For restrained foreign output to be zero, the foreign firm's profit would be zero. For sufficiently high restrained foreign output, the domestic firm would revert to use the Stackelberg strategy and the foreign firm's profit would be the some as that in the unrestrained case. In Proposition 3, the foreign firm's profit with $\hat{q}_{2}=q_{2}{ }^{*}$ is shown to be higher than that in the unrestrained case for $\phi^{\prime}()>$. 0 . The continuity properties of the demand function and the cost functions implies the existence of a range of restrained foreign output $\left(q_{2}, \bar{q}_{2}\right)$ such that the foreign firm's profit is higher under a restraint than that under free trade. 


\section{Appendix $E$}

\section{Diagrammatic Analysis}

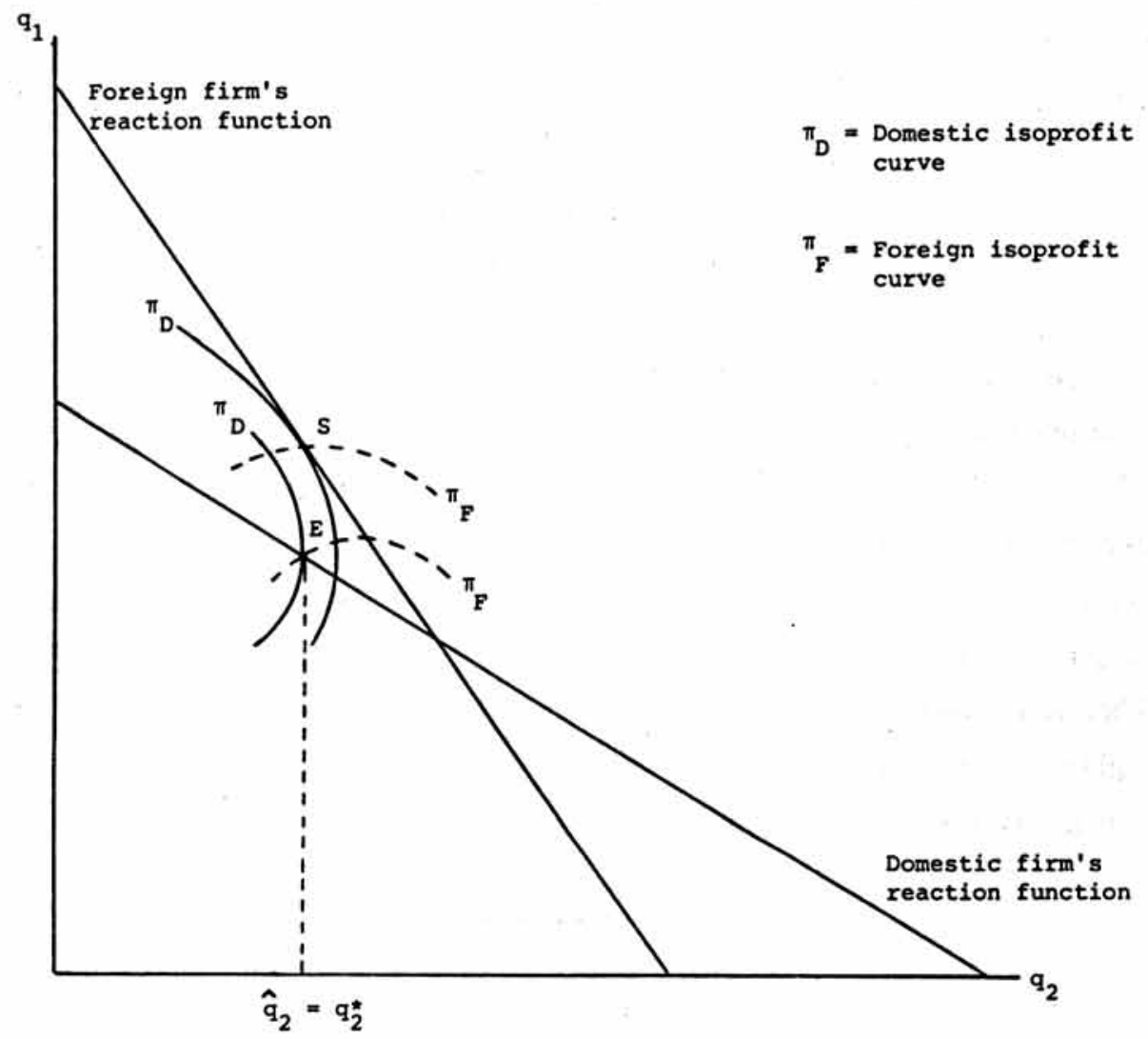

Figure 1

In the case when the foreign firm's reaction function is downward sloping as in Figure 1, $\mathrm{S}$ is the free trade (Stackelberg) equilibrium. With a foreign output restraint at $\hat{q}_{2}=q_{2}{ }^{*}$, E is the new equilibrium point. One can easily observe that profits of both firm increase as a result of the restriction. 


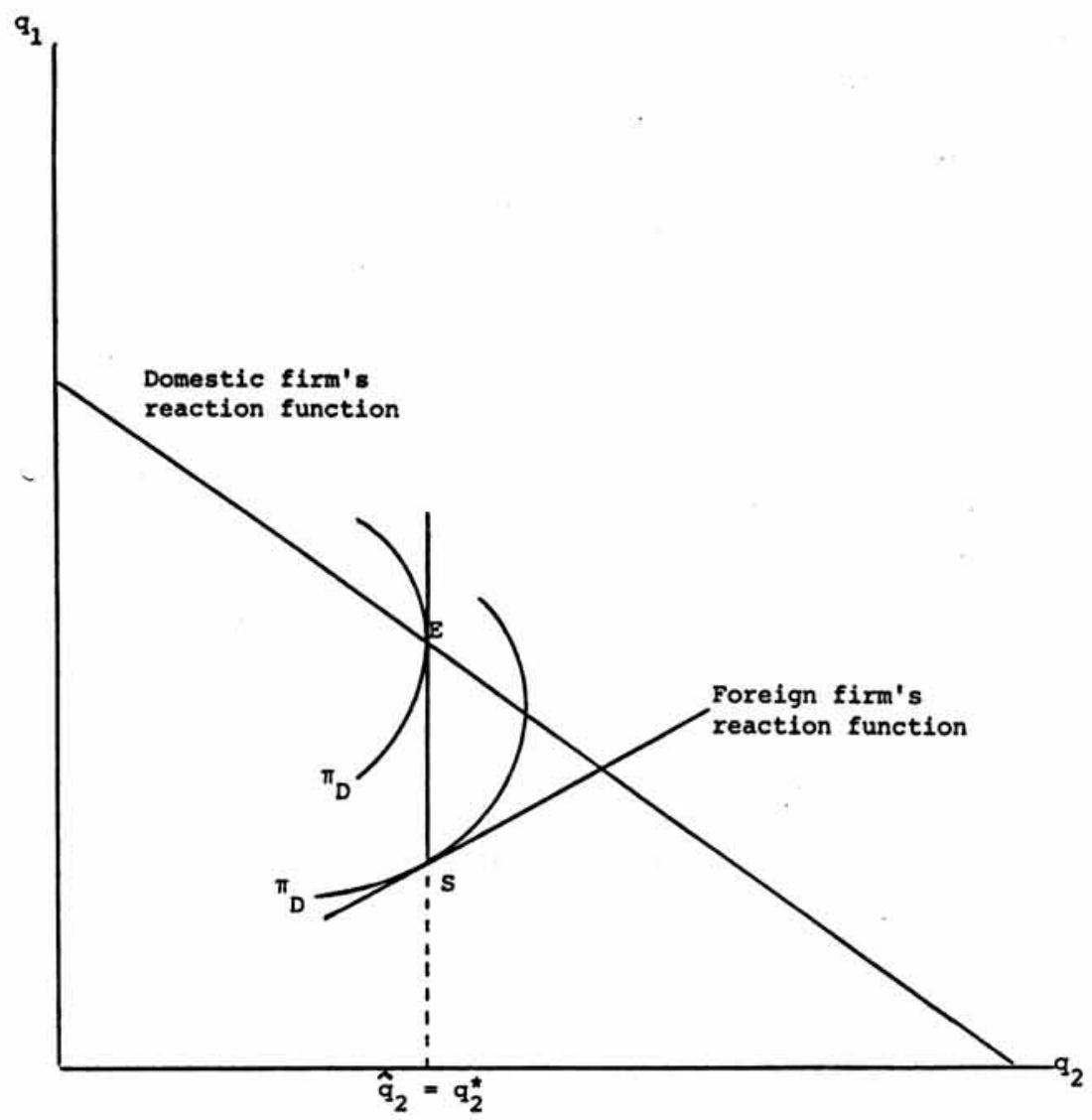

Figure 2

In the case when the foreign firm's reaction function is positively sloped, an imposition of a foreign output restriction of $\hat{q}_{2}=q_{2}{ }^{*}$ yields the equilibrium point $\mathrm{E}$. Total market output and the domestic firm's profit increase. A socially preferred situation for the domestic country would result from a quota. 


\section{References}

Bhagwati, Jagdish (1965), "On the Equivalence of Tariffs and Quota," in: R. E. Baldwin et al., eds., Trade, Growth and the Balance of Payments - Essays in Honor of G. Haberler (Rand McNally, Chicago), 53-67.

Bhagwati, Jagdish (1968), "More on the Equivalence of Tariffs and Quotas," American Economic Review, 58, 142-146.

Bhagwati, Jagdish (1987), "VERs, quid pro quo DFI and VIEs: Political-Economy-Theoretic Analysis,” International Economic Journal, Spring, 1-14.

Brecher, Richard A. and Jagdish N. Bhagwati (1987), "Voluntary Export Restrictions versus Import Restrictions: A Welfare-Theoretic Comparison,” in: H. Kierzkowski, ed., Essays in Honour of W. M. Corden (Basil Blackwell, Oxford).

Dinopoulos, Elias and Mordechai E. Kreinin (1989), "Import Quotas and VERs: A Comparative Analysis in a Three-Country Framework," Journal of International Economics, 26, 169-178.

Feenstra, Robert C. (1984), "Voluntary Export Restraints in US Autos, 198082: Quality, Employment and Welfare Effects,” In Robert E. Baldwin and Anne O. Krueger (eds), The Structure and Evolution of Recent U.S. Trade Policy, Chicago, University of Chicago Press (for National Bureau of Economic Research).

Feenstra, Robert C. (1985), "Automobile Process and Protection: The U.S.Japan Trade Restraint," Journal of Policy Modeling , 7, No. 1, 49-68.

Formby, Layson and Smith (1982), "The Law of Demand, Positive Sloping Marginal Revenue, and Multiple Profit Equilibria," Economic Iriquiry, 20, 303311.

Fung, K. C. (1989), “Tariffs, Quotas, and International Oligopoly,” Oxford Economic Papers, 41, 749-757.

Itoh, M. and Y. Ono (1984), “Tariffs, Quotas, and Market Structure," Quarterly Journal of Economics, 17, 359-374.

Harris, Richard, G. (1985), "Why Voluntary Export Restraints are 'Voluntary'," Canadian Journal of Economics, 18, No. 4, 799-809.

Kreinin, Modedechai E. (1984), “Auto VER with Japan and Product Upgrading (a Comment)," in: Baldwin and Krueger, eds., The Structure and Evolution 
of Recent U.S. Trade Policy, University of Chicago Press, Chicago, IL.

Krishna, K. (1983), "Trade Restrictions as Facilitating Practices," Discussion Paper No. 55, Woodrow Wilson School, Princeton University.

Krishna, K. (1989), "Trade Restrictions as Facilitating Practices," Journal of International Economics, 226, 251-270.

Lizondo, Jose Saul (1984), “A Note on the Nonequivalence of Import Barriers and Voluntary Export Restraints," Journal of International Economics, 16, $183-7$.

Makowski, Louis (1987), “Are 'Rational Conjectures' Rational?," Journal of Industrial Economics, 36, 35-47.

McCulloch, R. (1973), "When are a Tariff and a Quota Equivalent?," Canadian Journal of Electronics, 6, 504-511.

Rodriguez, C. (1974), "The Non-equivalence of Tariffs and Quotas under Retaliation," Journal of International Economics, 4, 295-298.

Takacs, Wendy E. (1978), "The Non-equivalence of Tariffs, Import Quotas and Voluntary Export Restraints," Journal of International Economics, 8, 565573. 